\title{
BIOMETAL AND HEAVY METAL CONTENT IN THE SOIL-NETTLE (Urtica dioica L.) SYSTEM FROM DIFFERENT LOCALITIES IN SERBIA
}

Vladimir D. Dimitrijevićc ${ }^{*}$, Nenad S. Krstić ${ }^{1}$, Maja N. Stanković1 ${ }^{1}$ Ivana Arsić ${ }^{\text {, }}$ Ružica S. Nikolić ${ }^{1}$

(ORIGINAL SCIENTIFIC PAPER) UDC 546.3:582.635.5:577.164.2:631.42

${ }^{1}$ Faculty of Science and Mathematics, Department of Chemistry, University of Niš, Niš,Serbia

2 Faculty of Medicine, Department of Pharmacy, University of Niš, Niš,Serbia

The content of some biometals ( $\mathrm{Fe}, \mathrm{K}, \mathrm{Mg}, \mathrm{Zn}$, and $\mathrm{Mn}$ ), and two heavy metals ( $\mathrm{Pb}$ and $\mathrm{Cd}$ ) in nettle (Urtica dioica L.) and in the respective soils were determined by ICP-OES. The samples were collected from two locations in the vicinity of Niš and one from Western Serbia. The amount of vitamin $C$ in the samples was determined by iodometric titration. The aim of the study was to determine the percentage of fulfilling the daily needs for tested biometals and vitamin $C$ by consuming nettle as tea or as vegetable, as well as to determine the amount of biometals that plants absorb from the soil. The obtained amount of $\mathrm{Fe}, \mathrm{K}, \mathrm{Mg}, \mathrm{Zn}, \mathrm{Mn}$ and vitamin $\mathrm{C}$ suggested that nettle can be used as an additional remedy in the treatment of anemia, and to alleviate the effects due to the lack of biometals. Some biometals were absorbed to certain saturation and some for as long as they were present in the soil.
Keywords: biometals, vitamin C, heavy metals, nettle, bioavailability, soils

\section{Introduction}

Nettle is an interesting plant species that has traditionally been used in the Balkan Peninsula for prevention and treatment of nutritional anemia. It grows on a variety of soils and in a wide geological zone. Therefore, it has often been the subject of study of many authors [1-3]. Phytochemical studies have suggested that nettle leaf contains chlorophyll, flavonoids, carotenoids, vitamins (C, B-group, $\mathrm{K}_{1}$, etc.), triterpenoids, sterols (betasitosterol), minerals, various organic acids, tannins, etc. Nettle stings contain amine (histamine, serotonin and others) [4].

Besides iron $(\mathrm{Fe})$ as the most interesting bioelement, nettle contains other biometals. Potassium $(\mathrm{K})$, magnesium $(\mathrm{Mg})$, iron $(\mathrm{Fe})$, zinc $(\mathrm{Zn})$ and manganese $(\mathrm{Mn})$ are involved in various enzymes and biomolecules. In the human body, they are in an ionized form as inorganic components (so called "minerals"), or in the form of inorganic components within the organic biomolecules [5].

Plants take biometals from the soil mostly in the form of hydroxyl, chloride, carbonate or hydrate complexes of different solubility and bioavailability.

Excessive amounts of these metals can cause chronic intoxication and major issues due to their ability to accumulate in various tissues and organs. $\mathrm{Pb}$ and $\mathrm{Cd}$ are not biometals, but according to their physico-chemical characteristics they can replace biometals in certain biomolecules [6].

Meers et al. [7] studied the content of $\mathrm{Zn}$ in nettle, while Konieczyński and Wesołowski [8] expanded their scientific work and examined Fe besides $\mathrm{Zn}$. Selected microelements in the plants from the territory of Turkey were the subject of research done by Acikgoz and Karnak [9].

The content of the trace elements in the samples of various plants among which was nettle from the territory of Turkey was investigated by Tokalioğlu [10], while a similar study for the area of Poland was carried out by Pytlakowska et al. [11]. Gjorgieva et al. [12] conducted a similar investigation for the region of Macedonia, while the information of the content of trace elements in plants used for medicinal purposes in Serbia can be found in the work of Mihaljev et al. [13].

Heavy metals are rarely present in the plants in concentrations that are high enough to be a risk of acute poisoning. It is necessary to determine the heavy metals concentration to know that the use of certain plants in the diet will not cause any harmful effects. On the other hand, it is important to find out which plant species may potentially be used in phytoremediation to remove heavy metals from the contaminated soil [14].

Başgel and Erdemoğlu [15] and Nica et al. [16] investigated the content of $\mathrm{Cd}$ and $\mathrm{Pb}$ in plants, as well as their potential health hazards. It was also confirmed that nettle can be used as an indicator of the accumulation of heavy metals in contaminated soils i.e. the idea of effective use of nettle in phytoremediation is justified.

\footnotetext{
*Author address: Vladimir Dimitrijević, Faculty of Science and Mathematics, Department of Chemistry, University of Niš, Višegradska 33, P.O. Box 224, 18000 Niš, Serbia

E-mail: vladimir15041987@gmail.com

The manuscript received: February, 24, 2016.

Paper accepted: March, 03, 2016.
} 
Availability of almost all biometals in the body is linked to the presence of vitamin C. Humans do not have the ability to create it, so they have to get it through the diet. The absorption of ascorbic acid depends on the amount of its input, whereby the method and temperature of storage and preparation of foods play a role in the vitamin $\mathrm{C}$ content [17-20].

Nettle is one of the highly valued, scientifically recognized medicinal plants and, therefore, it is used in different preparations of modern phytotherapy. Curative raw materials are leaf and ground part. Nettle leaf is used for producing various phytotherapeutic products which are used in the treatment of anemia, rheumatism and benefits of various metabolic disorders, as well as a strengthening agent. The fruit of nettle contains proteins, mucus, fatty oil, tocopherol, etc [4].

The aim of this study was to determine other trace elements except iron ( $\mathrm{K}, \mathrm{Mg}, \mathrm{Zn}$ and $\mathrm{Mn}$ ) in the plant which is traditionally used in the treatment of nutritional anemia in Serbia. Also, it was necessary to determine the level of fulfilling the recommended daily needs which is provided by drinking the nettle tea or consuming nettle as a dietary supplement in nutrition. At the same time, the aim was to determine the level of potential risks to human health due to the presence of highly toxic elements cadmium and lead, and their bioavailability.

\section{Experimental}

\section{Reagents}

All chemicals were of analytical grade, stock solutions were purchased from Merck (Germany), and deionized water of high purity was used (conductivity $0.05 \mu \mathrm{Scm}^{-1}$ ).

\section{Sample preparation}

The samples were collected at three locations by a standard procedure (at least $300 \mathrm{~m}$ from the main road, $100 \mathrm{~m}$ from the local road, and $5 \mathrm{~m}$ from the forest road at the depth of $0-30 \mathrm{~cm}$ ). The first site (L1) is located 14 $\mathrm{km}$ from the center of Niš, at an altitude of 290 meters. The sampling place was the waterside of the stream where the soil is silicate (Permian sandstones). The second sampling site (L2) is located $16 \mathrm{~km}$ from the center of Niš, at an altitude of 580 meters. The sampling place is humus-sandy sediment of the stream where the soil is limestone. The third site (L3) is located $320 \mathrm{~km}$ from Niš, at an altitude of 970 meters. The samples were taken from the magnesite mine tailing. Sampling was done in April 2013. The collected samples are exposed in the Herbarium of Faculty of Science and Mathematics in Niš. The metal content in the soil and plants were determined by ICP-OES. Each soil type is characterized by the EDS spectra using the electron microprobe technique.

Determination of metals in plant material and in respective soils

Three probes of soil ( $1 \mathrm{~g}$ per probe with an accuracy of $\pm 0,0001 \mathrm{~g}$ ) were measured and the same amount of plant material from each site. The samples of soil were dried in the oven at temperatures of $110-150{ }^{\circ} \mathrm{C}$. The percentage of moisture in the samples was around $25 \%$. One group of soil samples was treated with boiling water $\left(\mathrm{SLnH}_{2} \mathrm{O}\right)$ and the other with cold hydrochloric acid ( $S L n H C l)$. The samples were filtered and filtrates were standardized to specified volume. The metal content in the filtrates were determined by ICP-OES. The precipitate from the filter paper which remained after the treatment with cold hydrochloric acid was treated with hot hydrochloric acid $\left(80^{\circ} \mathrm{C}\right)$, filtered and then standardized for ICP-OES analysis.

The samples of the plant material were dried in the oven at temperatures of $110-150{ }^{\circ} \mathrm{C}$, and then annealed at temperatures up to $500{ }^{\circ} \mathrm{C}$. After that, the samples were mineralized (conc. $\mathrm{HNO}_{3} / \mathrm{conc}$. $\mathrm{HCl}(1: 2, \mathrm{v}: \mathrm{v})$ added in portions $\left(\mathrm{t}=80^{\circ} \mathrm{C}\right)$ and finally standardized for ICPOES analysis $[21,22,23]$.

\section{Determination of vitamin C}

The collected samples of nettle were air-dried and ground in an agate mortar. Three probes of $1.0000 \mathrm{~g}$ were measured from each location. After that, the samples were treated with boiling water for $10 \mathrm{~min}$. for one set of samples and $30 \mathrm{~min}$ for another. All samples were then filtered.

Standard solutions of $\mathrm{KIO}_{3}, \mathrm{H}_{2} \mathrm{SO}_{4}$ and $\mathrm{Na}_{2} \mathrm{~S}_{2} \mathrm{O}_{3}$ (p.a. analytical grade) were prepared by measuring the appropriate weight of each and adding the deionized water to the appropriate volume. The amount of vitamin $\mathrm{C}$ in the samples was determined by iodometric titration [24].

\section{Results and discussion}

The results of the analyses of selected biometals in topsoils, as well as in the plant (Urtica dioica L.) are shown in Tables 1 and 2 . The results are given as the mean value of three measurements.

Table 1. The biometal content in soil samples from the localities L1, L2, L3

\begin{tabular}{|c|c|c|c|c|c|}
\hline \multirow{2}{*}{ Sample } & \multicolumn{5}{|c|}{ Concentration [mg/kg dry mass] } \\
\hline & $\mathrm{Fe}$ & $\mathbf{M g}$ & $\mathrm{Zn}$ & $\mathbf{K}$ & Mn \\
\hline $\mathrm{SL}_{\mathrm{H}_{2} \mathrm{O}}$ & $8.54 \pm 0,08$ & $14.42 \pm 0.18$ & $0.87 \pm 0.01$ & $95.76 \pm 2.58$ & $1.09 \pm 0.02$ \\
\hline$S L 1_{\mathrm{HCl}}$ & $8184.07 \pm 143.55$ & $2008.37 \pm 3.75$ & $21.46 \pm 0.18$ & $288.87 \pm 18.97$ & $83.29 \pm 0.41$ \\
\hline $\mathrm{SL} 2 \mathrm{H}_{2} \mathrm{O}$ & $19.31 \pm 0.10$ & $39.96 \pm 0.33$ & $1.98 \pm 0.03$ & $92.59 \pm 0.51$ & $2.47 \pm 0.03$ \\
\hline$S L 2 \mathrm{HCl}$ & $1525.67 \pm 12.66$ & $239.34 \pm 0.45$ & $32.06 \pm 0.04$ & $431.57 \pm 7.08$ & $8.53 \pm 0.02$ \\
\hline$S L 3_{2} \mathrm{O}$ & $3.06 \pm 0.04$ & $119.99 \pm 1.44$ & $0.70 \pm 0.03$ & $85.43 \pm 1.99$ & $0.14 \pm 0.00$ \\
\hline$S L 3_{H C l}$ & $10637.64 \pm 181.82$ & $>19500$ & $35.24 \pm 0.12$ & $463.79 \pm 28.60$ & $109.51 \pm 1.22$ \\
\hline
\end{tabular}


Table 2. The biometal content in the plant samples from localities L1, L2, and L3

\begin{tabular}{c|ccccc}
\hline \multirow{2}{*}{ Sample } & \multicolumn{5}{|c}{ Concentration [mg/g dry mass] } \\
& Fe & Mg & Zn & $\mathbf{K}$ & Mn \\
\hline$P L 1$ & $0.025 \pm 0.00$ & $3.408 \pm 0.04$ & $0.028 \pm 0.00$ & $24.69 \pm 0.47$ & $0.05 \pm 0.00$ \\
$P L 2$ & $0.098 \pm 0.00$ & $2.38 \pm 0.06$ & $0.035 \pm 0.00$ & $25.34 \pm 0.11$ & $0.04 \pm 0.00$ \\
$P L 3$ & $0.14 \pm 0.00$ & $5.72 \pm 0.05$ & $0.04 \pm 0.00$ & $18.52 \pm 0.12$ & $0.01 \pm 0.00$ \\
\hline
\end{tabular}

EDS spectrum of the soil sample is shown in Figure 1. It can be seen that the soil sample contains a high percentage of oxygen minerals, minerals of silicon, magnesium and iron, and for this reason the samples which were treated with $\mathrm{HCl}$ have higher metal concentrations.

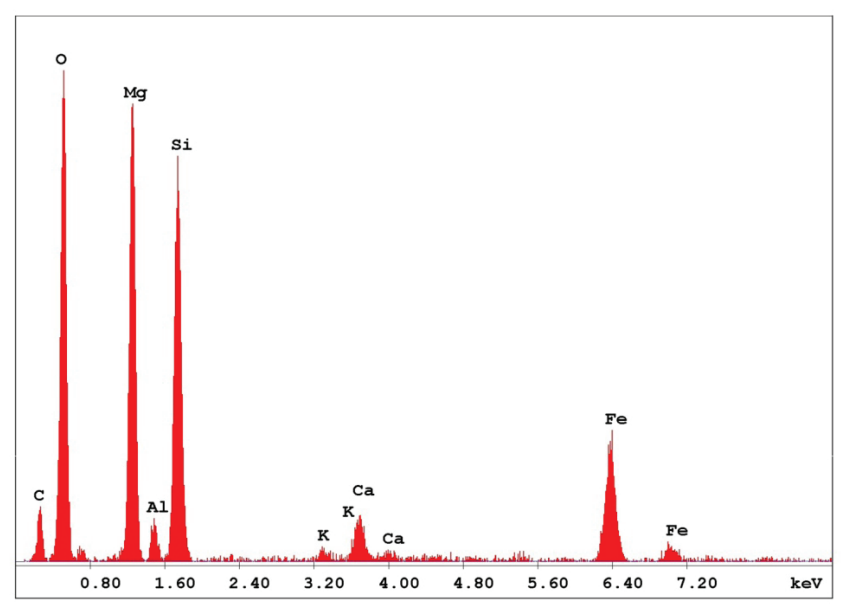

Figure 1. EDS spectrum of the soil from the locality L2

The results of the determination of metal and vitamin $\mathrm{C}$ in the plants are given in $\mathrm{mg} / \mathrm{g}$ since the weight of the bag of purchased tea is about $1 \mathrm{~g}$ and in this way it was easier to establish the correlation.

Bioavailability of analyzed metals is shown in Figure 2. Bioavailability was calculated by dividing the metal concentration in the plant samples with the metal concentration in soil samples (PL1/SL1 $\mathrm{HCl} \times 100 \%)$.

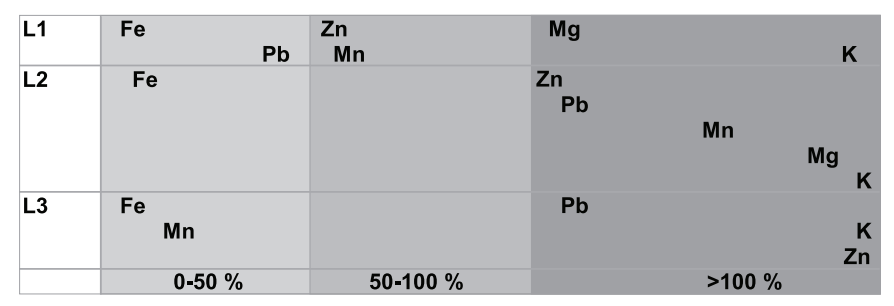

Figure 2. Bioavailability of biometals and lead in the soil-plant system

The content of vitamin $C$ in nettle was quite uniform for studied localities. After the $10 \mathrm{~min}$. treatment with boiling water it ranged from $32 \mathrm{mg} / \mathrm{g}$ to $35 \mathrm{mg} / \mathrm{g}$, and after the $30 \mathrm{~min}$. treatment it remained almost the same $(33 \mathrm{mg} / \mathrm{g}$ to $35 \mathrm{mg} / \mathrm{g}$ ) indicating that a cup of nettle tea fulfills more than half of the daily need for this vitamin and helps in utilization of trace elements (biometals).

Table 3. The recommended daily allowance (RDA) for biometals ( $\mathrm{Fe}, \mathrm{Mn}, \mathrm{Mg}, \mathrm{K}$ and $\mathrm{Zn}$ ) for adults [25]. The percentage of fulfilling daily needs by consuming $50 \mathrm{~g}$ of fresh nettle, and the percentage of fulfilling the daily needs by consuming a cup of tea

\begin{tabular}{|c|c|c|c|c|c|}
\hline Biometal & $\mathrm{Fe}$ & $\mathrm{Mn}$ & $\mathrm{Mg}$ & $\mathrm{K}$ & $Z n$ \\
\hline $\begin{array}{l}\text { RDA for adults } \\
\text { [mg] }\end{array}$ & 14 & $\begin{array}{c}2.3 \text { (male) } \\
1.8 \text { (female) }\end{array}$ & 300 & 4700 & 15 \\
\hline $\begin{array}{l}\text { The percentage of } \\
\text { fulfilling RDA for } \\
\text { adults concuming } \\
50 \mathrm{~g} \text { of fresh } \\
\text { nettle [\%] }{ }^{*}\end{array}$ & $8.0-37.5$ & $\begin{array}{c}32.6-81.5 \\
\quad(\text { male }) \\
41.7-104.2 \\
\quad \text { (female) }\end{array}$ & $42.5-71.3$ & $14.4-20.0$ & 7.5 \\
\hline $\begin{array}{l}\text { The percentage of } \\
\text { fulfilling RDA for } \\
\text { adults consuming } \\
\text { a cup of tea [\%] }\end{array}$ & $0.2-1.0$ & $\begin{array}{c}0.9-2.2 \\
\text { (male) } \\
1.1-2.8 \\
\text { (female) }\end{array}$ & $1.1-1.9$ & $0.4-0.5$ & 0.2 \\
\hline
\end{tabular}

Potassium has the largest content of all biometals in the examined samples of plants. This element is important because it maintains the acid-base balance in the human body, as well as the osmotic pressure. It plays a significant role in the transmission of nerve impulses in the muscle contractions [26,27]. Comparing the potassium content in the soil and a respective plant it is obvious that the plant adopts $\mathrm{K}$ in a very large percentage so it can be concluded that the plant absorbs virtually all $\mathrm{K}$ found in the soil. Therefore, this element is highly bioavailable. The percentages of utilization for all three localities clearly show that plant samples from silicate soil show as much as 10 times greater value for this parameter compared to those from other soils type. The potassium content of $18 \mathrm{mg} / \mathrm{g}$ to $25 \mathrm{mg} / \mathrm{g}$ found in plant samples covers about $0.4-0.5 \%$ of recommended daily allowance for this biometal for adults by consuming a cup of tea.

Iron is one of the most important bioelements because it builds hemoglobin and myoglobin, and also enters the composition of enzymes that play a role in a respiratory function $[28,29]$. The highest content of $\mathrm{Fe}$ in the plant samples, as well as the samples of soil was found at the magnesite mine tailing. However, the highest percentage of utilization of Fe was found for the sample from humus-sandy sediment of the stream with 
limestone soil. The content of $0.03 \mathrm{mg} / \mathrm{g}$ to $0.14 \mathrm{mg} / \mathrm{g}$ shows that consuming the nettle tea fulfills $0.2-1.0 \%$ of RDA for iron. Considering that nettle can also be used in the fresh condition as a supplement in diet, the intake of $50 \mathrm{~g}$ of fresh nettle would lead to fulfilling of $8.0-37.5 \%$ of an adult's daily needs.

Zinc represents an essential component for normal functioning of biomembranes. It also has a very important role in the metabolism of proteins and carbohydrates. It is necessary for the synthesis of DNA, as well as in the normal functioning of reproductive organs $[5,30]$. The content of $\mathrm{Zn}$ in plants is quite uniform regardless of the sampling location. The amount of $\mathrm{Zn}$ contained in the respective soils was about $0.03 \mathrm{mg} / \mathrm{g}$, which covers about $0.2 \%$ of the daily requirement. The percentage of utilization indicates that $\mathrm{Zn}$ belongs in highly bioavailable elements. There is a noticeable difference in the percentage of utilization between plants from different localities. The percentage of utilization of about $50 \%$ was found for the locality with the silicate soil, while the other 2 types of tested soil types showed the percent of utilization of over $100 \%$.

Magnesium plays an important role in many biochemical and physiological processes in the body so the daily needs of this element are high $[31,32]$. It belongs to highly bioavailable elements with the percentage of utilization of more than $100 \%$. The highest content of $\mathrm{Mg}$ was found in the plant samples and soil from magnesite mine tailings, which was expected considering the type of the substrate. The concentrations of $\mathrm{Mg}$ in the plants were from $3.4 \mathrm{mg} / \mathrm{g}$ to $5.7 \mathrm{mg} / \mathrm{g}$ which shows that one cup of tea fulfills about $1.1-1.9 \%$ of RDA for magnesium. Manganese participates in the metabolism of lipids. It also has a role in the formation of the skeleton, energy production and synthesis of nucleotides in DNA. It is closely connected with the content of Fe whereby Mn resorption will increase if there is a deficit of $\mathrm{Fe}[5,33]$. The highest content of $\mathrm{Mn}$ in plant samples were determined from the waterside of the brook where the soil is silicate, and in the soil samples from the magnesite mine tailing. However, the highest percentage of utilization in the plant samples was found in the samples from humussandy sediment of the stream where the soil is limestone, as much as 30 times higher than for plants from magnesite mine tailings. This indicates that plants from this locality were adapted to uptake the maximum amount of $\mathrm{Mn}$ which can be found in the soil in order to satisfy their needs for this bioelement. The amount of $\mathrm{Mn}$ was from $0.02 \mathrm{mg} / \mathrm{g}$ to $0.05 \mathrm{mg} / \mathrm{g}$ which fulfills 0.9 to $2.2 \%$ of RDA for male, i.e. 1.1 to $2.8 \%$ of RDA for female.

The results of the analysis of selected toxic metals in the soils and respective plants are shown in Table 4. The results are given as the mean value of three measurements.

Besides biometals that are useful for the human body, two toxic heavy metals, $\mathrm{Pb}$ and $\mathrm{Cd}$, were found in the samples. These two heavy metals are particularly dangerous because they tend to accumulate in the human body [14,34].
Lead accumulates in the bones, liver and kidneys. Poisoning by this heavy metal has serious consequences on the function of the brain and nervous system [5,34]. Plants accumulate $\mathrm{Pb}$ showing higher values for this heavy metals in the samples of the plants comparing to the same from the ground. The percentage of utilization was approximately the same for the limestone soil and magnesite mine tailings and at the same time it was about 5 times higher than in siliceous soil. The highest values of $\mathrm{Pb}$ in plants is related to the samples from the magnesite mine tailings. However, it is important to note that these values $(2.2 \mathrm{mg} / \mathrm{kg}$ to $3.4 \mathrm{mg} / \mathrm{kg})$ are significantly lower than the median lethal dose for lead (76.6 mg per kg of body weight).

Table 4. The content of toxic, heavy metals in soils and plants from the localities L1, L2, and L3

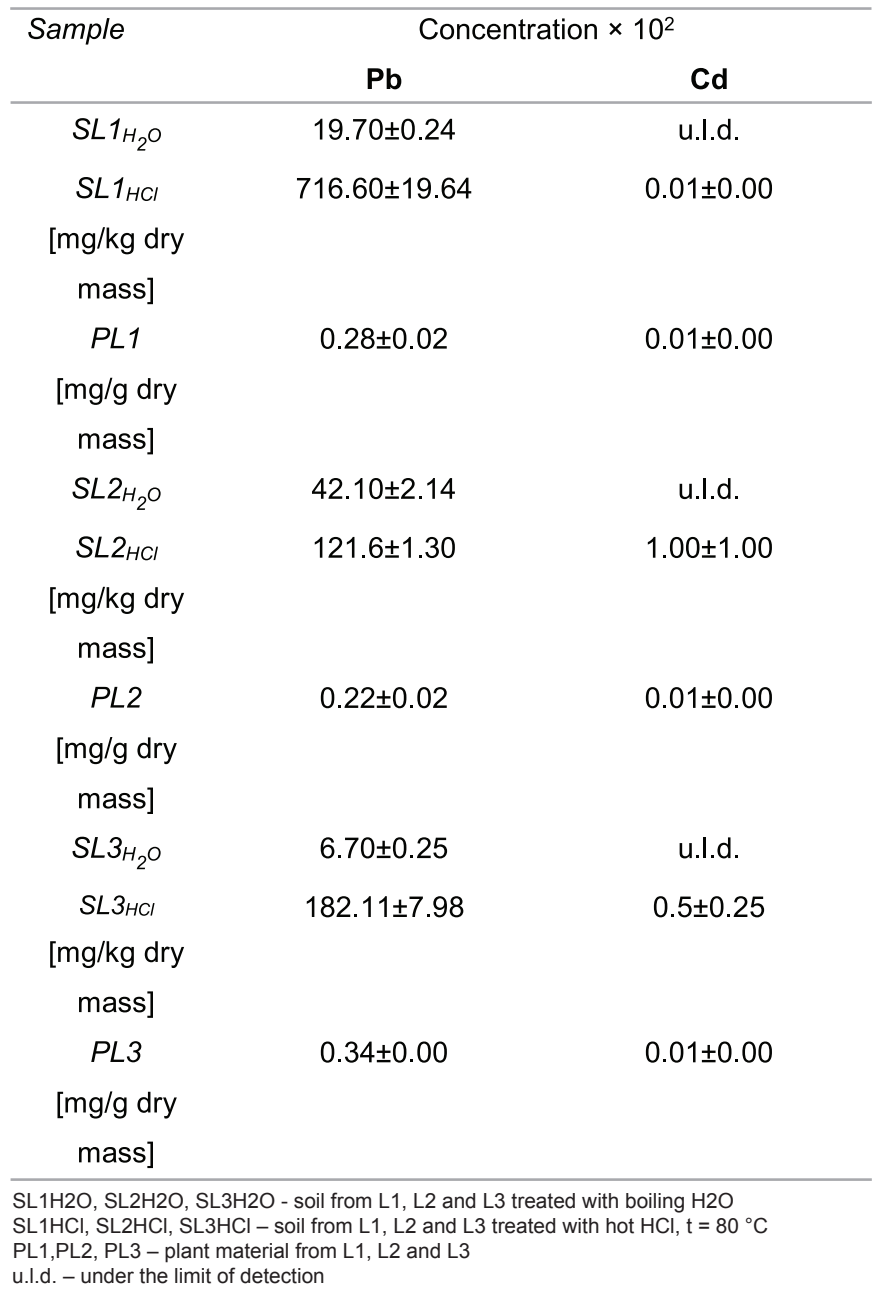

Cadmium has an effect on the skeleton and bone deformation and its accumulation in kidneys can cause tissue damage. It has a devastating effect on the heart. Also, it is important to point out that $\mathrm{Cd}$ is among carcinogenic elements [5,34]. Cadmium was present in very small quantities in the investigated soil, from $0.005 \mathrm{mg} /$ $\mathrm{kg}$ to $0.010 \mathrm{mg} / \mathrm{kg}$. All Cd which was taken from the soil by plant was precipitated in the plant, so a higher concentration of this metal was found in plants $(0.050 \mathrm{mg} / \mathrm{kg}$ 
to $0,095 \mathrm{mg} / \mathrm{kg}$ ) than in a respective soil. These values are significantly below the median lethal doses for this metal (3.7 $\mathrm{mg}$ per $\mathrm{kg}$ of body weight). The amounts of $\mathrm{Cd}$ found in plants show that there is no danger of poisoning due to the consumption of tea of the analyzed nettle, but one should be careful when collecting the plant material.

\section{Conclusion}

The results of determination of the biometals content in nettle (Urtica dioica L.) have shown that this plant, which has traditionally been used in the Balkan Peninsula in the treatment of nutritional anemia for centuries, contains very high amounts of $\mathrm{Fe}$ and significant amounts of other biometals ( $\mathrm{Mg}, \mathrm{Zn}, \mathrm{Mn}$ and $\mathrm{K}$ ) which satisfies a certain percentage of the daily requirement for these trace elements.

Each of the studied soils contained a relatively high percentage of these elements in comparison with their mean content in the Earth's crust. The results showed a different tendency of concentrating for each of the analyzed elements. The percentage of utilization or bioavailability for Fe was low (less than $5 \%$ ) while for $\mathrm{Mg}$ and $\mathrm{K}$ it was above $100 \%$. The percentage of utilization of $\mathrm{Mn}$ and $\mathrm{Zn}$ varies depending on the sampling location, although in the case of $\mathrm{Zn}$ it can be seen that it was always higher than $50 \%$.

The results have shown that nettle has a tendency to accumulate $\mathrm{Pb}$ which may be used in phytoremediation of polluted soil. Also, the content of heavy metals should be controlled when consuming the nettle tea. A special attention should be paid when someone individually collects the plant material.

Consuming a cup of tea or fresh nettle as a dietary supplement can satisfy a certain percentage of the daily requirement for $\mathrm{Fe}$ and other examined biometals $(\mathrm{K}, \mathrm{Mg}$, $\mathrm{Zn}$, and $\mathrm{Mn}$ ). Considering that it is possible to consume more than one cup of tea per day, as well as consuming plants as a supplement, it can be concluded that nettle (Urtica dioica L.) is an excellent nutrient for fulfilling a high percentage of the recommended daily allowance for adults for examined biometals.

\section{Acknowledgements}

Authors would like to thank the Serbian Ministry of Education, Science and Technological Development (Grant No TR34008, III 45017) for financial support. Also, we are grateful to Bojan Zlatković, the associate professor at the Department of Biology (Faculty of Science and Mathematics in Niš) for helping us to collect and categorize plant and soil materials.

\section{References}

[1] R. B. Mack, Lead in history, Clinical Toxicology Bulletin, 3 (1995) 7-44.

[2] M. L. Leporatti, S. Ivancheva, Preliminary comparative analysis of medicinal plants used in the traditional medicine of Bulgaria and Italy, Journal of Ethnopharmacology, 87(2-3) (2003) 123-142.

[3] S. Jarić, Z. Popović, M. Mačukanović-Jocić, L. Djurdjević, M. Mijatović, B. Karadžić, M. Mitrović, P. Pavlović, An ethnobotanical study on the usage of wild medicinal herbs from Kopaonik Mountain (Central Serbia), Journal of Ethnopharmacology, 111(1) (2007) 160-175.

[4] I. Arsić, S. Đorđević, D. Runjaić-Antić, M. Ristić, Funkcionalnom hranom protiv tegoba anemije, Zbornik radova 10. Naučno-stručnog skupa Ishrana i zdravlje: Minerali, vitamini, drugi dodaci hrani i njihov zdravstveni značaj, Naučnoistraživački centar Užice, 3D Grafika, 2004, p. 56-60.

[5] S. M. Petrović, S. R. Savić, M. Lj. Dimitrijević, Ž. B. Petronijević, The determination of micro and macroelements in chamomile teas (Matricaria chammomilia L.), Advanced technologies, 4(2) (2015) 37 42.

[6] S. Razić, A. Onjia, S. Dogo, L. Slavković, A. Popović, Determination of metal content in some herbal drugsEmpirical and chemometric approach, Elsevier, Talanta, 67 (1) (2005) 233-239.

[7] E. Meers, F. M. G. Tack, M. G. Verloo, Zn content in stinging nettle (Urtica dioica L.) as affected by soill characteristics: spatial distribution and statistics, 17th WCSS paper No. 2300, Thailand, 2002, p. 1-11.

[8] P. Konieczyński, M. Wesołowski, Determination of Zinc, Iron, Nitrogen and Phosphorus in Several Botanical Species of Medicinal Plants, Polish Journal of Environmental Studies, 16(5) (2007) 785-790.

[9] M. A. Acikgoz, E. E. Karnak, Micro-nutrient composition of some medicinal and aromatic plants commonly used in Turkey, Scientific Papers. Series A. Agronomy, 56 (2013) 169-173.

[10] S. Tokalioğlu, Determination of trace elements in commonly consumed medicinal herbs by ICP-MS and multivariate analysis, Food Chemistry, 134 (2012) 25042508.

[11] K. Pytlakowska, A. Kita, M. Janoska, V. Kozik, Multielement analysis of minerals and trace element in medicinal herbs and their infusion, Food Chemistry, 135 (2012) 494-501.

[12] D. Gjorgieva, T. Kadifkova-Panovsk, K. Bačeva, T. Stafilov, Metalic Trace Elements in Medicinal Plants from Macedonia, Middle-East Journal of Scientific Research, 7 (1) (2011) 109-114.

[13] Ž. Mihaljev, M. Živkov-Baloš, Ž. Cupić, S. Jakšić, Levels of some microelements and essential heavy metals in herbal teas in Serbia, Acta poloniae pharmaceutica, 71(3) (2014) 385-391.

[14] D. Dimitrijević, Hemija otrovnih hemijskih supstanci, skripta, Ministarstvo odbrane, Sektor za ljudske resurse, Uprava za školstvo, Vojna akademija, Beograd, 2008.

[15] S. Başgel, S. B. Erdemoğlu, Determination of mineral and trace elements in some medicinal herbs and their infusions consumed in Turkey, Science of the Total Environment, 359 (2005) 82-89.

[16] D. Nica, D.M. Bordean, I. Gergen, Comparative assessment of trace metal accumulation in celery and nettle leaves, JHFB, 16(2), (2012) 217-220.

[17] M. A. Alen, S. G. Burgess, The Losses of Ascorbic Acid during the Large-scale Cooking of Green Vegetables by Different Methods, British Journal of Nutrition, 4(2-3) (1950) 95-100. 
[18] M. G. Roig, Z. S. Rivera, J. F. Kennedy, A model study on rate of degradation of $L$-ascorbic acid during processing using home-produced juice concentrates, International Journal of Food Sciences and Nutrition, 46(2) (1995) 107115.

[19] M. Levine, C. Conry-Cantilena, Y. Wang, R. W. Welch, P. W. Washko, K. R. Dhariwal, J. B. Park, A. Lazarev, J. F. Graumlich, Vitamin C pharmacokinetics in healthy volunteers: evidence for a recommended dietary alowance, Proceedings of the National Academy of Sciences of the United States of America, 93(8) (1996) 3704-3709.

[20] J. Higdon, Vitamin C, Oregon State University, Micronutrient Information Center, 2006.

[21] D. S. Velimirović, S. S. Mitić, S. B. Tošić, B. M. Kaličanin, A. N. Pavlović, M. N. Mitić, Levels of Major and Minor Elements in Some Commercial Fruit Juices Available in Serbia, Tropical Journal of Pharmaceutical Research, 12(5) (2013) 805-811.

[22] R. Nikolić, N. Krstić, V. Dimitrijević, I. Arsić, J. Jovanović, M. Nikolić, Essential biometals (Fe, Zn, Mg, Mn, K) in the tea mixtures for the treatment of nutritional anemia in the Balkan peninsula (Serbia), 5th BBBB international conference, Athens, 2013.

[23] S. S. Ranđelović, D. K. Kostić, B. B. Arsić, G. Stojanović, Bioaccumulation of metals in different species of mulberry, Advanced technologies 3(2) (2014) 105-110.

[24] J. Trajković, J. Baras, M. Mirić, S. Šiler, Analiza životnih namirnica, Tehnološkometaluški fakultet, Univeriteta u Beogradu, Beograd, 1983.
[25] S. Rose, Vitamins \& minerals, How to get the nutrients your body needs, Bounty Books, a division of Octopus Publishing Group Ltd, London, 2007.

[26] R. Nikolić, M. Đorđević, Biološki značaj natrijuma i kalijuma, Hemijski pregled, 6, (2009) 150-155.

[27] D. Veljković, G. N. Vučković, Minerali u ishrani, Hemijski pregled, 51 (2010) 14-19.

[28] N. Tasid, Đ. Radak, Z Cvetković, B. Petrović, N. Ilijevski, G. Đorđević-Debić, Uloga i značaj oligoelemenata u patogenezi arteoskleroze, Vojnosanitetski pregled, 61 (2004) 667-673.

[29] R. Nikolić, N. Krstić, Biološki značaj gvožđa, Hemijski pregled, 1 (2011) 19-26.

[30] M. S. Pešić, R. S. Nikolić, N. S. Krstić, Biološki značaj cinka, Hemijski pregled, 3 (2015) 70-75.

[31] M. E. Shils, in Magnesium in modern nutrition in health and diease, M. E. Shils, J. A. Olson, M. Shike, C. A. Ross, Eds., 9th Edition, Wlliams \& Wilkins, Philadephia, 1999, p. 169-192.

[32] N. S. Krstić, R. S. Nikolić, Biološki značaj magnezijuma, Hemijski pregled, 4 (2015) 89-94.

[33] N. Krstić, R. Nikolić, M. Krstić, Biološki značaj mangana, Hemijski pregled, 6 (2014) 154-157.

[34] B. Kaličanin, R.Nikolić, The Application of the Potentiometric Stripping Analysis to Determine Traces of $\mathrm{M}(\mathrm{II})$ Metals ( $\mathrm{Cu}, \mathrm{Zn}, \mathrm{Pb}$ and $\mathrm{Cd}$ ) in Bioinorganic and Similar Materials, in Wide Spectra of Quality Control, I. Akyar Ed., InTech, Rijeka, 2011, p. 211

Izvod

\section{SADRŽAJ BIOMETALA I TEŠKIH METALA U SISTEMU ZEMLJIŠTE-KOPRIVA (Urtica dioica L.) SA RAZLIČITIH LOKALITETA U SRBIJI}

Vladimir D. Dimitrijević ${ }^{1}$, Nenad S. Krstić ${ }^{1}$, Maja N. Stanković ${ }^{1}$, Ivana Arsić ${ }^{2}$,

Ružica S. Nikolić ${ }^{1}$

(ORIGINALNI NAUČNI RAD)

UDK 546.3:582.635.5:577.164.2:631.42

1 Departman za hemiju, Prirodno-matematički fakultet, Departman za hemiju, Univerzitet u Nišu, Niš,Srbija

2 Medicinski fakultet, Departman za Farmaciju, Univerzitet u Nišu, Niš,Srbija

Sadržaj nekih biometala (Fe, Mg, Zn, K i Mn), i dva teška metala ( $\mathrm{Pb}$ i Cd) u biljci koprivi (Urtica dioica L.) i odgovarajućem zemljištu određen je tehnikom ICPOES. Uzorkovanje je vršeno sa dva lokaliteta iz okoline Niša i jednom iz Zapadne Srbije Količina vitamina C u uzorcima određena jodometrijskom titracijom.. Cilj ispitivanja je utvrđivanje procenta ispunjenja dnevnih potreba za ispitivanim biometalima i vitaminom C konzumiranjem koprive u obliku čaja ili povrća u ishrani kao i utvrđivanje količine biometala koji biljke apsorbuju iz zemljišta. Količine pronađenog $\mathrm{Fe}, \mathrm{K}, \mathrm{Mg}, \mathrm{Zn}, \mathrm{Mn}$ i vitamina C ukazuju da se kopriva može koristiti kao pomoćno lekovito sredstvo u lečenju anemije ali i ublažavanju posledica usled nedostatka biometala u ishrani. Utvrđeno je da biljka lako i u velikom procentu apsorbuje biometale koji se nađu u zemljištu, neke do određenog zasićenja a neke dok god in ima u zemljištu na kome raste.

Teški metali su pronađeni u vrlo niskim koncentracijama kako u zemljištu tako i u biljkama pa se može zaključiti da ne predstavljaju opasnost po zdravlje ljudi. Procenat apsorpcije $\mathrm{Pb}$ od strane biljaka ukazuje na to da se kopriva potencijalno može koristiti u fitoremedijaciji zemljišta.
Ključne reči: biometali, vitamin $C$, teški metali, kopriva, bio-dostupnost, zemljište 